\title{
Morbidity, its Patterns and Associated Factors among School Children Residing in a North Indian City
}

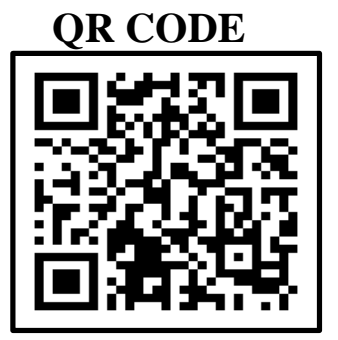

\section{SEBASTIAN CHRISTIAN, MANASVI DUGGAL ${ }^{2}$, SHALINI DEHAL ${ }^{1}$}

INTRODUCTION: Children are the pillars of the future of a country shall rest, are no less than a treasure and need to be as healthy as possible. AIM: To assess the health status of school children in various areas of Una city, Himachal Pradesh, India.

MATERIALS AND METHOD: The present study was conducted among school children aged 7-18 present on the day of the study. Data collected was cross-sectionally using a pre-validated and pre-tested questionnaire duly standardized prior to commencement of the study. The first section of the questionnaire contained details about the demographic profile, and in the second, the examiners recorded the presence or absence of common childhood diseases, namely pallor, lymphadenopathy (L.N.), Bitot spots, Worm infections, Scabies, Ear discharge, Dental caries and Fluorosis. Statistical analysis included the Shapiro-wilk test to check for data normalcy, followed by descriptive statistics and Pearson's correlation. Significance value (p) was kept significant at $\leq 0.5$.

RESULTS: Most children belonged to the age group of 12-15 years (42.8\%), followed by 7-11 years(34.3\%) and 16-18 years(22.9\%). Majority of the students were girls $(61.5 \%)$ and most them belonged to the age group of $12-15$ years $(41.0 \%)$. Disease in any from was observed in $813(76.2 \%)$ of the children, with the most prevalent disease observed being dental caries (32.3\%), followed by fluorosis (20.5\%) and pallor (14.3\%). Pearson's correlation revealed a strong, positive association between the disease status and age (0.7) and gender ( 0.8$)$

CONCLUSION: The results of the present study indicate the need to have various specific programmes to reduce the burden of various diseases, namely dental caries and pallor among school children through efforts of various programmes.

\section{INTRODUCTION}

Children, who are god's greatest gifts and are the foundation on which the pillars of the future of a country shall rest, are no less than a treasure and need to be as healthy as possible. However, in some places, communities still are deprived of essentials such as clean water and proper health-care facilities. ${ }^{1}$ Even so, there are reports stating that the quality of life among school children, by most standards continues to be poor in certain parts of the globe, especially in rural areas and urban slums. ${ }^{2}$

The present position with regard to the health and nutritional status of the children in our country is very unsatisfactory, with mortality being low, but morbidity and physical defects constitute heavy burden, even when under the ICDS Scheme; freshly, cooked food supplements are provided to children aged 3-6 years while take-home-rations of food grains are provided to children aged 6 months until 3 years. ${ }^{3}$ School health programs can help to ensure that children are healthy and able to take full advantage of what is often their first and only opportunity for formal education. ${ }^{4}$

Health surveys in Indian schools indicate that morbidity and mortality rates of children of primary school age are among the highest in the World. ${ }^{5}$ Under nutrition continues to be a primary cause of ill-health and premature mortality among children in developing countries. ${ }^{6}$ Under nutrition among children is prevalent in almost all the states in India. ${ }^{7}$

Surveys carried out indicate that the main emphasis will fall in malnutrition, infectious diseases, intestinal parasites, diseases of skin, eye and ear and dental caries. ${ }^{8}$ These health problems can make learning difficult and may seriously hamper the educational process and the child's intellectual growth and may also handicap the child for life. Keeping all these facts in view, a need was felt to assess the health status of school children in various areas of Una city, Himachal Pradesh, India.

\section{MATERIALS AND METHODS}

The present study was conducted among school children aged 7-18 years after obtaining proper approvals from the concerned authorities. Students absent on the day of the examinations were excluded from the study.

(C) Sebastian Christian et al. This is an open access article distributed under the terms of the Creative Commons Attribution License CC-BY-NC 4.o, which permits unrestricted use, distribution and reproduction in any medium, provided the use is not commercial and the original author(s) and source are cited. Submitted on: 06-Oct-2021; Accepted on: 21-Nov-2021 
Data collected was cross-sectionally using a prevalidated and pre-tested questionnaire by examiners (including the dentist) duly standardized prior to commencement of the study. The first section contained details about the demographic profile, and in the second, the examiners recorded the presence or absence of common childhood diseases, namely pallor, lymphadenopathy (L.N.), bitot spots, worm infections, scabies, ear discharge, dental caries and fluorosis.

Statistical analysis included the Shapiro-wilk test to check for data normalcy, followed by descriptive statistics and Pearson's correlation. Significance value (p) was kept significant at $\leq 0.5$.

\section{RESULTS}

Table 1 describes the gender-wise distribution of the children. It was observed that most children belonged to the age group of 12-15 years (42.8\%), followed by 7-11 years $(34.3 \%)$ and $16-18$ years $(22.9 \%)$. Majority of the students were girls $(61.5 \%)$ and most them belonged to the age group of $12-15$ years $(41.0 \%)$.

\begin{tabular}{|c|c|c|c|}
\hline AGE & BOYS $(\%)$ & $\begin{array}{c}\text { GIRLS } \\
(\%)\end{array}$ & $\begin{array}{c}\text { TOTAL } \\
(\%)\end{array}$ \\
\hline 7-11 years & $166(40.4)$ & $200(30.4)$ & $366(34.3)$ \\
\hline 12-15 years & $188(45 \cdot 7)$ & $269(41.0)$ & $748(42.8)$ \\
\hline $\begin{array}{c}16-18 \\
\text { years }\end{array}$ & $57(13.9)$ & $187(28.6)$ & $185(22.9)$ \\
\hline Total & $411(38.5)$ & $\begin{array}{c}656 \\
(61.5)\end{array}$ & $1067(100)$ \\
\hline
\end{tabular}

Table 1. Age and Gender Wise Distribution of the Schoolchildren

Disease in any from was observed in $813(76.2 \%)$ of the children. Upon further analysis, the most prevalent disease observed was dental caries (32.3\%), followed by fluorosis (20.5\%) and pallor (14.3\%). The least percentage of disease observed was Worm infection( $8.2 \%)$ followed by L.N.(3.6\%) (table 2).

\begin{tabular}{|c|c|c|}
\hline \multicolumn{1}{|c|}{ DISEASE } & NUMBER & PERCENTAGE \\
\hline Pallor & 117 & 14.3 \\
\hline L.N & 29 & 3.6 \\
\hline Bilot spot & 61 & 7.5 \\
\hline Worm infection & 67 & 8.2 \\
\hline Scabies & 36 & 4.5 \\
\hline Ear discharge & 74 & 9.1 \\
\hline Fluorosis & 166 & 20.5 \\
\hline Dental Caries & 263 & 32.3 \\
\hline
\end{tabular}

Table 2. Prevalence of various diseases among the Schoolchildren (LN: lymphadenopathy)
Analysis of the data by the Pearson's correlation revealed a strong, positive association between the disease status and age (0.7) and gender (o.8) (table 3).

\begin{tabular}{|l|l|l|} 
& AGE & GENDER \\
\hline Disease Status & 0.7 & 0.8 \\
\hline
\end{tabular}

Table 3. Pearson's Correlation Relating the Disease Status of The Children with Age And Gender

\section{DISCUSSION}

The results of the present study documented disease in any from among $76.2 \%$ of the children, with the most prevalent disease observed was dental caries (32.3\%), followed by fluorosis (20.5\%) and pallor (14.3\%).

The overall prevalence of $38.5 \%$ boys and $61.5 \%$ females observed in the present study is in contrast to the observed prevalence of Utkarsh S et al. 9 (59.5\% males \& 40.5\% females) and Dambhare et al. (68.97\% males and $31.03 \%$ girls). ${ }^{2}$

Children enrolled in the present study revealed an overall presence of $32.3 \%$ of dental caries, which was lower as compared to the findings of Syed $\mathrm{S}$ et al. $(56.24 \%)^{10}$, and higher as compared to Shakya SR et al. $(19.8 \%)^{11}$ and Phuljhele $S$ et al. (10.91\%). ${ }^{12}$

Worm infection among the children was observed as $8.2 \%$; and this percentage was higher as compared to Khanal LK et al. $(17.6 \%)^{13}$ and higher as per Singh JP et al. (2.50\%). ${ }^{14}$ These findings indicate that plans of the government as well as other not for profit organizations have helped reduced the burden of this worm infections.

The second most prevalent disease observed among children was fluorosis $(20.5 \%)$ and this was low as per the findings of Shekar C et al. $(71.5 \%)^{15}$ and Sebastian ST et al. (41.73\%). ${ }^{16}$ Such variations can be attributed to the presence of fluoride belts, increased presence fluoride in of water as well and the intake of fluoridated water by the mother during pregnancy.

\section{CONCLUSION}

Based on the results of the present study, there is a need to have various specific programmes to reduce the burden of various diseases, namely dental caries and pallor among school children through efforts of various programmes of the government and assistance of various not-for profit organizations. 


\section{REFERENCES}

1. UNICEF. The State of the World's Children 2012: Children in an Urban World. UNICEF, 2012. Available at: http://www.unicef.org/sowc2012/ (last accessed on February 8, 2015).

2. Dambhare DG, Bharambe MS, Mehendal AM, Garg BS. Nutritional status and morbidity among school going adolescent in Wardha. A peri urban area. Internet J Epidemiol. 2010;9:40-8.

3. ICDS Mission, The Broad Framework for Implementation published by Ministry of Women and Child Development, Government of India 2012

4. Jones J, Hoffmann-Barthès AM. Focusing Resources on Effective School Health (FRESH). Available at: http://www.unesco.org/ (last accessed on February 6, 2014).

5. e: Ragavendra S K, Praveen G, Shashank K J. A study on morbidity profile among primary school children in the rural field practice area of a medical college in Karnataka. MedPulse International Journal of Community Medicine 2019; 11(1):7-12. https://doi.org/10.26611/10111112

6. Nandy S, Irving M, Gordon D, Subramanian SV, Smith GD; Poverty, child undernutrition and morbidity: new evidence from India. Bull World Organ., 2005; 83(3):210-6.

7. Som S, Pal M, Bhattacharya B, Bharati S, Bharati P. Socieconomic differentials in nutritional status of children in the states of West Bengal and Assam. J Biosoc Sci., 2006; 38(5):625-42.

8. Chauhan N, Trivedi A. Prevalence of Vitamin A Deficiency in Urban Slums of Ahmedabad, India. Germany: Lambert Academic Publishing; 2011
9. Sharma U, Sharma JP, Sharma A. Morbidity Pattern among School going Children in Urban Area of Dehradun. Int J Sci Stud. 2015;3(1):179-82.

10. Syed S, Gangam S, Syed S, Rao R. Morbidity patterns and its associated factors among school children of an urban slum in Hyderabad, India. Int J Med Sci Public Health. 2015;4:1277-81. https://doi.org/10.5455/ijmsph.2015.30032015264 11. Shakya SR, Bhandary S, Pokharel PK. Nutritional status and morbidity pattern among governmental primary school children in the Eastern Nepal. Kathmandu Univ Med J (KUMJ). 2004;2(4):307-14.

12. Phuljhele S, Solanki D.K, Netam S. Nutritional status and morbidity pattern of children aged 6-6o months beneficiaries of anganwadi at urban slums area of Raipur city in Central India. Int J Pediatr Res. 2019;6(05):226-32.doi:10. 17511/ijpr.2019.io5.06 13. LK Khanal, DR Choudhury, SK Rai, J Sapkota, A Barakoti, R Amatya and S Hada. Prevalence of intestinal worm infestations among school children in Kathmandu, Nepal. Nepal Med Coll J 2011; 13(4):272-74. 14. Singh JP, Kariwal P, Gupta SB, Singh AK, Imtiaz D. Nutritional status and morbidity among school going children: A scenario from a rural India. Sch J App Med. Sci. 2014; $2(1 \mathrm{D}): 379-83$.

16. Sebastian ST, Soman RR, Sunitha S. Prevalence of dental fluorosis among primary school children in association with different water fluoride levels in Mysore district, Karnataka. Indian J Dent Res. 2016;27:151-4. https://doi.org/10.4103/o970-9290.183126

Cite this article as:

Christian S, Duggal M, Dehal S. Morbidity, its Patterns and Associated Factors among School Children Residing in a North Indian City. Int Healthc Res J. 2021;5(7)OR7-OR9. https://doi.org/10.26440/IHRJ/0508.11475

AUTHOR AFFILIATIONS: (*Corresponding Author)

1. M.Pharm, Consultant Pharmacist, Una, Himachal Pradesh, India

2. B.PT, Sahdeo Polyclinic, Jhajjar, Haryana, India

Source of support: Nil, Conflict of interest: None declared

Contact Corresponding Author At: editor[dot]ihrj[at]gmail[dot]com 